
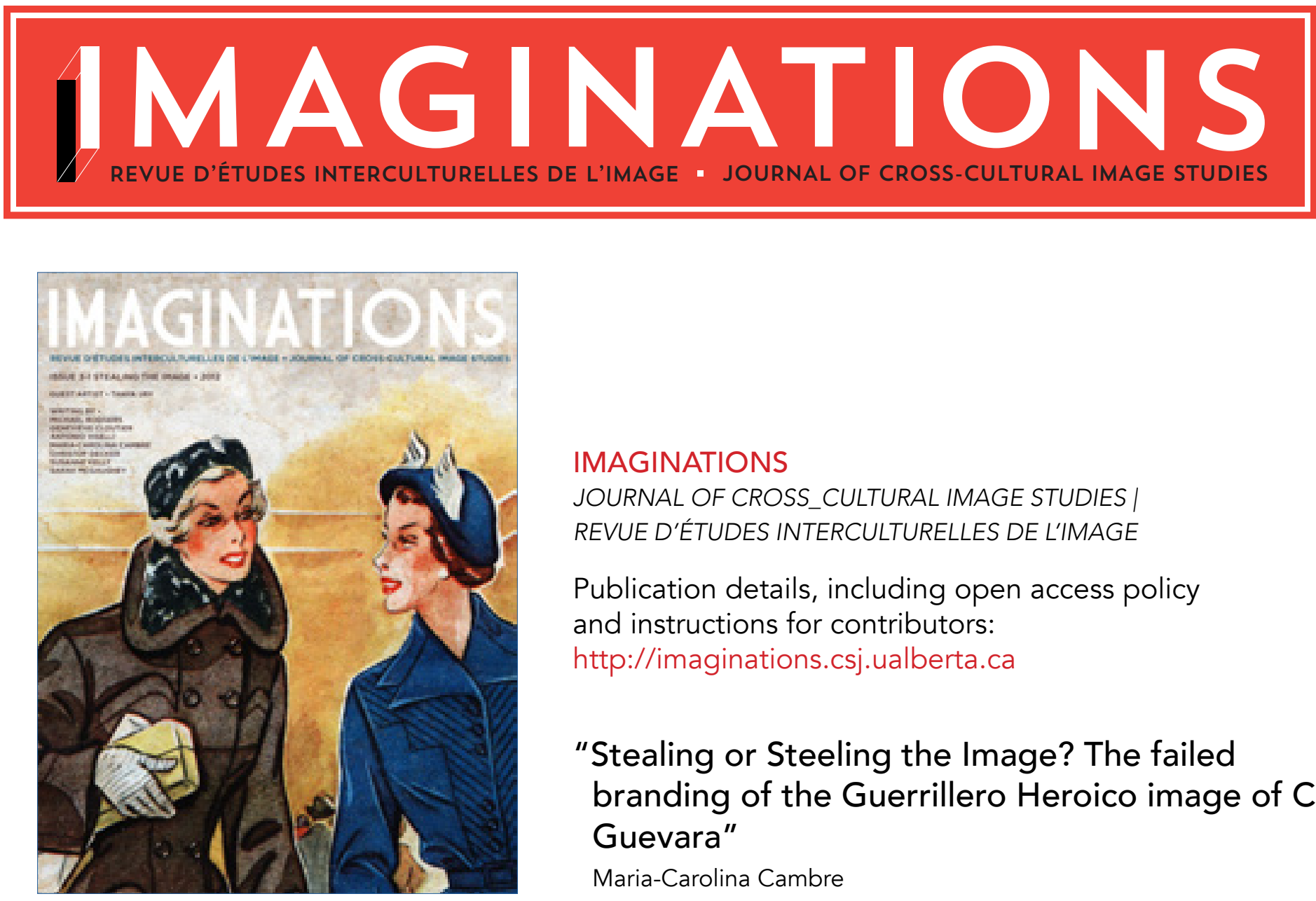

\title{
IMAGINATIONS
}

JOURNAL OF CROSS_CULTURAL IMAGE STUDIES |

REVUE D'ÉTUDES INTERCULTURELLES DE L'IMAGE

Publication details, including open access policy and instructions for contributors:

http://imaginations.csj.ualberta.ca

\section{"Stealing or Steeling the Image? The failed branding of the Guerrillero Heroico image of Che Guevara"}

Maria-Carolina Cambre

May 21, 2012

To Cite this Article:

Cambre, Maria-Carolina. "Stealing or Steeling the Image? The failed branding of the Guerrillero Heroico image of Che Guevara" Imaginations 3:1 (2011): Web (date accessed) 64-87. DOI: 10.17742/IMAGE.stealimage.3-1.8

To Link to this article:

http://dx.doi.org/10.17742/IMAGE.stealimage.3-1.8

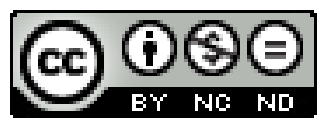

The copyright for each article belongs to the author and has been published in this journal under a Creative Commons Attribution NonCommercial NoDerivatives 3.0 license that allows others to share for non-commercial purposes the work with an acknowledgement of the work's authorship and initial publication in this journal. The content of this article represents the author's original work and any third-party content, either image or text, has been included under the Fair Dealing exception in the Canadian Copyright Act, or the author has provided the required publication permissions. 




\title{
THE FAILED BRANDING OF THE GUERRILLERO HEROICO IMAGE OF CHE G GUEVt VARA
}

MARIA-CAROLINA CAMBRE, UNIVERSITY OF ALBERTA

\begin{abstract}
This article traces the ongoing tension between those who would characterize Alberto Korda's famous image of Che Guevara, The Guerrillero Heroico, as a brand, trademark or logo, and those who insist it is a political/cultural icon and non-commercial and that these categories are mutually exclusive. The questions of whether the image has been emptied of political content, and the debate around the copyrighting of an image considered by many to be in the public domain and a cultural icon are explored. The long-lasting struggle over the meanings and collective memories associated with this image indicate the possibility that both processes of commodification and radicalization of the image of Che Guevara can coexist. Using the literature on consumer research to engage definitions of branding as a commercially geared venture, this article teases out the problematics of different uses of the photograph and its derivatives, and highlights ambiguities around the notions of creation and authorship. After examining this image's role within Cuba, Cuban use outside of Cuba, and its commercial and non-commercial uses by non-Cubans, I conclude that attempts at branding products with this particular image fail, and therefore its copyrighting is irrelevant.
\end{abstract}

\section{Résumé}

Cet article suit la trace historique d'une tension persistante autour de la photo célèbre de Che Guevara intitulée "Guerrillero Heroico » et prise par Alberto Korda. Cette tension prend place entre ceux qui la caractérisent comme une marque déposée ou un logo et ceux qui insistent sur sa valeur de symbole politique et culturel non-commercial. Ces catégories s'excluent mutuellement. Sont examinés la lutte pour les droits de propriété intellectuelle de cette image que beaucoup considèrent comme un symbole culturel du domaine public, ainsi que la possibilité que cette image ait perdu sa valeur politique. La persistance de ce débat sur les significations et les formes de mémoires collectives qu'on y associe indiquent la possibilité que le processus de marchandisation peut coexister avec celui de radicalisation en ce qui la concerne. Cet article fait ressortir le problème de la variété des emplois d'une image et de ses dérivés, en même temps qu'il souligne les ambiguités autour des concepts de création et de paternité en utilisant des études sur la consommation. Ayant évalué le rôle de cette image à l'intérieur des frontières de Cuba, son emploi par les cubains à l'extérieur du pays, ainsi que ses emplois commercial et non-commercial par les autres, je conclus que la commercialisation de cette image est vouée à l'échec et qu'il est inutile de rechercher ces droits de propriété intellectuelle. 
So join the struggle while you may

The revolution is just a $t$-shirt away Waiting For The Great Leap Forwards Billy Bragg

El derecho de autor realmente no tiene razón de ser. Yo no tengo derechos. Al contrario, tengo deberes ${ }^{1}$ Jean-Luc Godard (quoted by Lañamme and Kaganski)

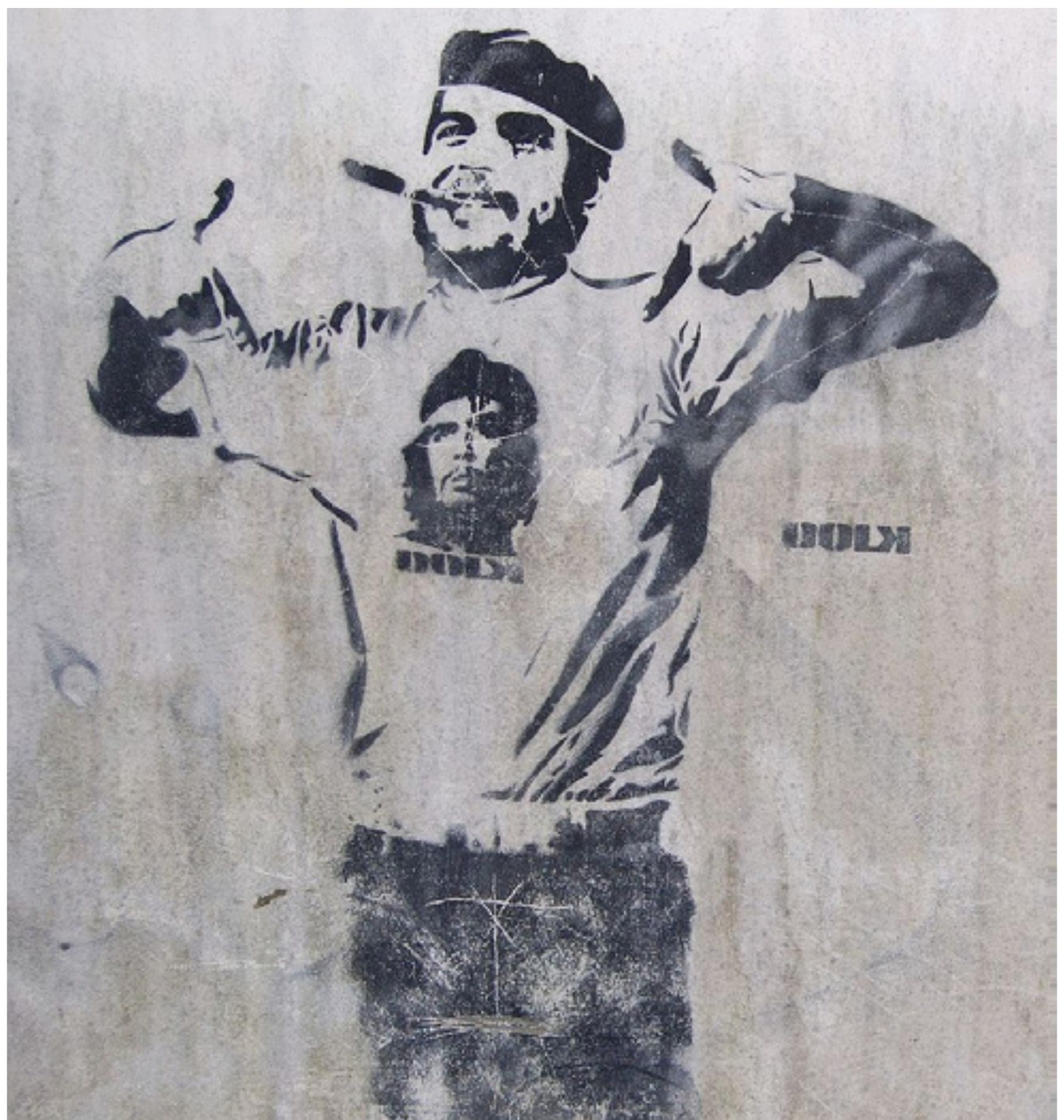




\section{Background}

Through an examination of the controversies surrounding the use of the Guerrillero Heroico, the famous Che Guevara photograph taken in March 1960 by Alberto Díaz Gutiérrez (familiarly known as Korda), in a Cuban context within and outside of Cuba, and finally the non-Cuban context, I examine some of the appropriations of and discourses traversing this image in order to illuminate its being located, or dislocated as the case may be, as a brand, commercial product, artwork and/or cultural artefact. Since its first publication the picture has inspired artists ${ }^{2}$ around the world to modify and render it in a myriad of media and styles. ${ }^{3}$ However, when Smirnoff's UK advertising agency wanted to use the image to sell vodka in 1999, Korda, who had made no issue with previous iterations, sued them. "The ads depicted Che's face adorned with a pattern of hammers and chilli-pepper sickles, not to foster communist consciousness in a creative redeployment of commodity fetishism, but simply to promote a new spice line of Smirnoff vodka" (Hernandez-Reguant 257). The company settled out of court and gave Korda a significant sum that he promptly donated to a hospital in Cuba. Regardless of the fame and accompanying profit potential from this photograph, Korda refused to endorse its commercialization or gain financially. Korda claimed using Che's image for selling vodka was a "slur on his [Guevara's] name" emphasizing that Che "never drank himself, was not a drunk, and [that] drink should not be associated with his immortal memory" (Sridhar).

After the international lawsuit Korda's rights as the author were recognized publicly and spokespeople for many media conglomerates in Europe and the United States saw it as an unprecedented move on the part of the Cuban government towards capitalism. The debate that had been bubbling under the surface for decades finally spilled onto mainstream headlines:

The Times of London wryly recast this development as if it were the Argentine revolutionary's own long and hard fought victory... 'After 40 Years, Che Beats Forces of Capitalism' (Bird 2000). CNN.com likewise dramatized the event, but with a slightly less ironic, and more-to-the-point, headline: 'Social Justice, Sí. Vodka Advertisements, No.' (HernandezReguant 256)

While the Times of London and CNN position the use of copyright in this case as distinctly non-commercial, Wall Street Journal correspondent Michael Casey takes the opposite stance. Casey, who wrote the only booklength English language (at the time) examination of Korda's Guerrillero Heroico comments, "Che had not beaten capitalism; he had joined it" (313) and dismisses the photograph, "copyright number VA-1-276-975," as no more than "a nine-character alphanumeric code" (337). In a more bizarre twist, Larson and Lizardo cite Alvaro Vargas Llosa calling the image of Guevara the "quintessential brand of capitalism" (426 my emphasis). Yet literature on this particular photograph and its subsequent renderings does not reveal evidence attesting to the purchasing of Guevara-sporting products merely in order to champion capitalism.

A historical perspective reveals that portraits of Guevara have tended to surface at key political moments. The New York Times of May 02, 1961 runs the headline "Castro Rules Out Elections in Cuba" (A2) on the first page with a large feature image. Apparently for May Day celebrations in 1961, before Guevara's death, "portraits of Karl Marx, Raul Castro, the Minister of Armed Forces, and Maj. Ernesto Guevara... [were] being carried by athletes in parade in Havana" (New York Times 1961, also noted in Larson and Lizardo 2007). This was not the Guerrillero Heroico but an official portrait of the sort often trotted out for political marches, and marking Guevara's face as part of the official visual equipment of the new government, without singling out his image in any special way.

With respect to the Guerrillero Heroico, the Cuban context is unique. After the news of Guevara's death, on Monday the $16^{\text {th }}$ of October $1967,{ }^{4}$ the Granma newspaper, official organ of the Communist Party in Cuba, printed a special edition dedicated to Che Guevara. The cover, a full-page image of Korda's Guerrillero Heroico, was so well received that it was 
reprinted the next day. On the night of the $18^{\text {th }}$, in the Plaza de la Revolución the same picture was hung as the background for the public stage from which Fidel Castro would say Guevara's eulogy. ${ }^{5}$ I learned of the impact of Castro's public eulogy through a series of in-depth online interviews (2009-2011) with Reinaldo Morales Campos, a Cuban historian who has studied political poster, propaganda and advertising history for over 30 years and has published in Spanish, English, French and German. ${ }^{6}$ Campos related how the eulogy extolling Guevara's intelligence, courage, and human sensibility as model revolutionary figure had the effect of fusing with Korda's picture in the minds of those who witnessed the event and "led to the image being taken up as an effigy of the Guerrillero Heroico to highlight his image worldwide" (personal communication).

After Feltrinelli's publication of Guevara's Bolivian Diaries in early 1968 with the Guerrillero Heroico on the cover and about a million posters promoting the book, there was a global explosion of reproductions, often in the form of protest posters. Larson and Lizardo observe that, "the New York Times repeatedly connected Che to Marxist social movements in Europe and the Americas" (428) around this time. In the 1960s, a bedroom "without a poster of Che Guevara was hardly furnished at all” (Storey 88). Jorge R Bermudez suggests a global transcendence of the Guerrillero Heroico signaling its use in the memorable days of the Parisian barricades in May 1968, in the slaughter of Mexican students in Tlatelolco, in clashes in Milan, during the Prague Spring uprising, and in youth protests in the USA against the Vietnam War.

Larson and Lizardo mark a significant peak of visibility in the USA at the time Guevara's remains were revealed in Bolivia in 1997. Tracing the discourses around Guevara in Spain and the United States from 19552006, they describe a tonal shift in the New York Times' headlines. For example the title, "From Rebel to Pop Icon" in the Arts Pages moves towards emphasizing the photograph's commercial quality by honing in on its accompaniment by a wave of products sporting the image (428). In this article, Doreen Carvajal interviews
Jim Fleischer of Fischer Skis who were reproducing Che's image on their promotional materials even while dissociating themselves from the man himself: "We felt that the Che image - just the icon and not the man's doings -represented what we wanted: revolution, extreme change" (New York Times C11). Somewhat confusingly, Carvajal also cites José Borges, a spokesman for the Cuban Mission to the United Nations: "We have always been against any commercial use of his image... one thing is to promote his image and his example, and another thing is to use it as a way to get more money" (New York Times C11).

Oddly Larson and Lizardo (2007) follow with what they position as the New York Times final words on the matter: "In light of this mountain of damning evidence, the New York Times concluded, In Europe and the United States, Che's image owes its commercial appeal to the absence of political content" (1997b, Tina Rosenberg). Making this statement look as if it is a conclusion is misleading because first, it is taken from a different article than the one they were using, and second, it is not a conclusion. Rather, it is one of the opening paragraphs in Tina Rosenberg's article "The World Resurrects Che," written months later on July 20, (E14) and followed by a letter to the editor, written in response on that very day, from a reader named David Silver entitled "Would Che have Turned Capitalist? Never!" (New York Times A20). Ironically, faces with this so-called "mountain of damning evidence" Silver (1997) protests: "Tina Rosenberg jumps to an unwarranted conclusion" (A20) grounding his claim with a citation from one of Guevara's letters to the editor of Marcha, a Uruguayan weekly newspaper. Silver (1997) underlines Guevara's stress on the danger of bourgeois ideology and its seductive appeal to oppressed and exploited people: "in capitalist society man is controlled by a pitiless law usually beyond his comprehension. The alienated human specimen is tied to society as a whole by an individual umbilical cord: the law of value'" (A20). Epitomized by this snapshot of exchanges published in the New York Times, the status of the meaning, memory and value of Che Guevara's image appears to be hotly contested. 


\section{The Politics of Branding}

More often than not, copyright law's purpose is to protect the author's right to obtain commercial benefit from work, ${ }^{7}$ but we know this was not Korda's goal. By having potential users of the image ask permission before availing themselves of it, copyright laws also safeguard an author's general right to control how a work is utilized. Can it be assumed that copyrighting means the image is automatically pressed into commercial service? Recent developments in legalities do not allow its meaning, value, and usage to be summed up so simply. For example, there are multitudinous artistic and vernacular renderings of the Guerrillero Heroico that Korda or his estate (managed by his daughter Diana Díaz) do not prosecute or pursue. Evidently, "what it [the image] has come to mean has been the subject of much speculation" (Poyner 34). Perhaps copyright laws are being applied in an unconventional way, a way that exceeds the frames and models of analysis usually applied through the Berne Convention and the multitude of nation-specific laws. Perhaps, we can examine the problematics of how different people take up the image, as well as how the image itself invokes and provokes action, to better understand the dynamics of appropriation.

The notions of brand, trademark and logo are often bandied about interchangeably with respect to the Guerrillero Heroico by those who would see its copyrighting as an appropriation of the image as a 'mark' of something. For the purposes of this article, I refer to logo as a graphic, and logotype as the lettering/ words: together logo and logotype form a trademark following the legal discourse. Brand then, refers to the entire package of graphics, name, messaging and communications, visual identity, marketing strategies, and individual experiences with the business, product or service. Robert E. Moore provides some definitional guidelines for understanding exactly what a brand, or what the essential ingredients for considering something a brand might be. According to Moore, "brands are often defined as a form of protection: they protect the consumer from counterfeit goods, and they protect the producer from unfair competition." Additionally, he observes that in an era where branding processes seem to encompass far more than products and services, and that all sorts of experiences, events, leaders, nations and even wars are being branded: "the absence from the academic literature of any semiotically sophisticated and ethnographically rich understanding of brands is downright shocking" (332). His article thoroughly addresses this lack, and provides a thoughtful sounding board to which I will periodically return to address some of the confusion around the Guerrillero Heroico.

According to one strategist, "if brand names did not exist there would be no trustworthy marketplace" (Moore 338). One of the key elements of a brand has to do with its trustworthiness or credibility. To elaborate, Moore turns to David Aaker, one of the most heavily cited authors in the brand strategy literature, who tells us that a brand is:

A distinguished name and/or symbol ... intended to identify the goods or services ... and to differentiate those goods or services from those of competitors. A brand thus signals to the customer the source of the product, and protects both the customer and the producer from competitors who would attempt to provide products that appear to be identical (qtd. in Moore 338).

Refining the definition of 'brand,' Moore calls it "a name and a logo, joined to a set of regimented associations, with source-identifying indexicals" and concludes: "a brand is a promise" (339). Accordingly, for the CocaCola company, we can understand the Polar Bear, Santa Claus, the wavy font type, the specific tone of red, team sponsorships, prizes and contests, songs like "I'd like to teach the world to sing" and slogans such as; "The real thing," "Always," "Open happiness," and "Enjoy" and even the traditional shape of the bottle to all be part of the brand designed to connect individuals to one company. The collection of elements is calculated by branding experts, with the product and consistent tradition of the one company in mind, aiming to make clear links in consumers' minds. 
What then would be the characteristics by which one might recognize Korda's Che image as a brand? More often than not the long hair, beard, star, beret, and eyes looking above and beyond the viewer, bomber jacket or a combination of all or some of these are featured by those who render the image to trigger recognition. One might say it is regularly linked to the notions of dissent, rebellion, revolution, youth, as well as non-conformity, anti-capitalism and anti-imperialism. But these notions lead us to no one place or group or even agreement on the meaning of an idea. Since many people, especially in Canada and the United States do not know who Guevara is or where he is from, or where or when the original photograph was taken, we have situations where an image is unmoored often from its human and historical source. Context is key. Yet, a crucial characteristic of a brand has precisely been identified as a credible and trustworthy connection to one source. This source is not necessarily the brand's designer rather it is most often the corporation whose product it has been designed to promote, and with which it is inextricably linked. One might imagine the multitudinous variations and interpretations as endless iterations of the original photograph, like a meme, which could take the position of a source. But another complication exists; a photograph is an index with a contiguous relationship to the source, the man himself.

Following this line of thinking then, the set of all these images would constitute the brand for the original source or photograph and so it might look like a ship whose anchor has lodged itself at the base of its own hull, in a self-referential semiotic circuit. But this is not the case because the image does not exist in a hermetically sealed closed sign system. Rather, it is part of some "...collective equipment that everyone is in a position to use, not in order to be subjected to their authority but as tools to probe the contemporary world" (Bourriaud 9). Each of the image's iterations also simultaneously bears the marks of the particular artist/designer and thus references the specific time, place, event or person that has intersected with the image in that rendering. This would seem to make the Guerrillero Heroico the actual antithesis of a brand if we accept Michael Casey's account of the logic of brand protection where: "Large companies are sticklers for the integrity of their brands. They worry about the size, colour, dimensions, and appropriate uses of their corporate logo... No McDonald's franchisee would ever be allowed to put up a blue Golden Arches sign" (334). Since "the most important characteristic of a brand is its credibility" (Erdem \& Swait 192), the protection of brands is serious business. ${ }^{8}$

Another aspect of branding to consider is the manner in which a group or corporation enacts their branding strategy. Invariably, they orchestrate the time and place of the "launch" in a hierarchical mass-produced fashion. Moore explains:

In the process of producing brands, branding professionals attempt to capture, and turn to their advantage, a set of fairly recondite- even, ineffablefacts about how brands circulate in society, even as they try to create the conditions that allow brands to circulate. So circulation is fundamentally part of the production process, even if not quantifiably so. The use of ethnographic methods represents an effort to uncover and understand likely patterns of circulation and consumption, in advance of production, every bit as much as efforts to develop the 'brand personality' are attempts further to define them. (352)

Because a company's products combine both tangible and intangible features, "value no longer inheres in the commodity itself as a tangible thing; rather, value inheres in something else, something less tangible: the aura, the simulacrum, the reproduction (as opposed to the original), the brand" (Moore 331). The immaterial aspects are unstable: they are open to interpretation and can shift with time and circumstance. Therefore, corporations go to great pains to protect the integrity of their brand names with complicated policy architectures because brands are inherently vulnerable. For example, when golf professional Tiger Woods was caught in an adultery scandal in 2009, Gatorade and other private enterprises stopped endorsing him and distanced themselves ${ }^{9}$ because as one branding expert noted, the 
Woods brand "was founded upon prestige, mystique... and an aura of elusive untouchability," but now "we all suddenly know more about his bottom-feeding behavior than we ever cared to" (Elliott 2010). We learn, in fact, that he was actually excessively touchable. Woods had been an image of prowess based on precision, integrity, and clarity of focus that metaphorically reflected a clear conscience. Woods had compromised that image with contradictory behaviour. In this scenario, those who attribute the amount of an enterprise's private market value in part to its name reevaluated the choice to endorse an athlete that might negatively impact the name, or more crucially, its market value.

The need to protect and control the perception of a brand's "name" shows not only the existence of inherent vulnerability to undesirable interpretations, but also that branding strategy is actually about deciding on a limited set of predetermined meanings deemed acceptable for a brand. In other words a branded product is:

... partly a thing, and partly language. The brand name functions as a 'rigid designator' in their terminology of Kripke (1972): it communicates information about the source, producer, and/or type of thing, and can provide quite rich sociocultural and ideological 'captioning' for the object (including by 'keying' it to definable activities) through the radical use of 'condensation symbolism' (Sapir, 1949 [1929]).” (Moore 334)

Simply put, terms like: rigid designator, ideological caption, or condensation symbolism describe the process of linking an object to a fiction designed to create a desire to consume them both, as J. B. Twitchell acknowledges in the Journal of Consumer Research, "a brand is simply a story attached to a manufactured object" (484). With its ultimate goal of selling products and augmenting commercial value, branding is a kind of planning, control, and action requires a centralized and concerted effort that is nonexistent in the case of the Guerrillero Heroico. But at the very core of this process is the manipulation of cultural sensibilities. Branding isn't just the unloading of stories on manufactured products but also the systematic suturing of cultural texts into commercial products. Patronizing certain products becomes a vicarious way of being part of the desirable realm of socially sanctioned values.

Che's image emerged somewhat organically, spontaneously and largely low-tech as in the case of street art and murals, outside of Cuba and more intentionally, through the state apparatus, within Cuba. The effervescing of the image here and there through different media and created by different hands almost simultaneously challenges the establishment of a clear line tracing its provenance, and perhaps that is part of its appeal. Still, this image has a very different history within Cuba than it does outside of Cuba; consequently, I examine them separately.

\section{Within Cuba}

One of the most relentlessly strident critiques of the Guerrillero Heroico's uses in Cuba is contained in Michael Casey's Che's Afterlife: The Legacy of an Image. Marshalling a carnival of opinions, anecdotes and interviews for support, Casey's overriding thrust is that the Guerrillero Heroico is the "quintessential capitalist brand" (30). However, in a scholarly and detailed book review, historian Maurice Isserman observes Casey's "book would have benefited greatly from a sturdier historical frame" and that he "seems overly enamored with the language of advertising and consumption" (Isserman). Casey's book provides detailed anecdotal accounts and personal interviews in Cuba, Argentina, Venezuela, Bolivia and Miami ${ }^{10}$ as well as a great deal of information on Korda himself that are worth addressing despite the historical inaccuracies that perforate his efforts to position Che Guevara as solely a socially constructed icon.

From the beginning, Casey positions the Cuban revolution as "a top-selling cultural product, an international brand, and....its ultimate expression: the Che-T shirt" (88). In a puzzling shift however he also writes: "Che was already available in 1968 in a wide variety of political brands" (129). Together these statements seem nonsensical: that the Cuban revolution is a brand represented by a 
Che T-shirt but that Che is simultaneously a variety of different political brands. If we make note of the brand literature alone, this would be at odds with the very raison d'être of branding. The representing of "different political brands" clouds our understanding of what Che represents, thus compromising clarity and credibility. Erdem and Swait's study establishes that, "the clarity (i.e., lack of ambiguity) of the product information contained in a brand is an antecedent to brand credibility" (192). It would seem the image is behaving in a way that is difficult to commercialize according to a brand strategy, and therefore difficult to categorize simplistically as a brand.

Casey's ahistoricism begs the question of history's relevance, and consequently politics' relevance for the so-called brand of the Guerrillero Heroico making it problematic for him to claim historical and political grounds for the image's prominence in the Cuban public's imaginary. His claim that the "Korda image launched into public consciousness in Cuba, where it was in effect employed as a logo or brand for Castro's PR campaign" (93), and assumption that the "general public, which had not seen a single photograph of Che since his mysterious disappearance in April 1965, was now shown an image" (186) are swiftly debunked by Isserman:

Mainstream American media, as well as the radical press, had kept Che's name and face in the public eye for years: from his days as Castro's sidekick, to his disappearance from view in Cuba in 1965, to his life as an international man of mystery until October 9, 1967.

So how did this myth of the Guerrillero Heroico as brand for Castro and Cuba arise? What happened in Cuba in the decades prior to the copyright lawsuit? First, the year 1968 was officially declared the year of the Guerrillero Heroico in Cuba to memorialize Guevara. Artists and designers in Cuba generated numerous works representing Che and the revolution to commemorate the first anniversary of Guevara's assassination. At the same time, artists were developing techniques and styles for poster art and evolving the unique genre of Cuban poster art. In those years Cuban designers were moving away from influences of advertising and realism and towards creative interpretation as an artistic vanguard influenced by pop art, art deco and other Japanese and North American art movements.

The international political context included large movements mobilizing against wars, dictatorships in Latin America and Africa, colonialism and the accompanying assassinations of important leftist leaders around the world. All of these movements against imperialist power and people fighting for social progress flowed into each other. This context created a creative environment where Korda's image became a malleable tool to be contextualized artistically in order to comment on history or current events, and produce salient political observations.

The Guerrillero Heroico quickly became a glyph in the exploration of collective memory by Cuban artists. Larson \& Lizardo describe collective memories as "traces of the past remembered and reenacted in the present, periodically reinvigorated in commemorations, celebrations, poetry, images, and other symbolic displays" (431). In their study, they analyze how memories of Che Guevara are produced after interviewing 3000 Spaniards across social, economic and generational lines between 1991 and 1993. Larson \& Lizardo conclude that, "Instead of his memory falling victim to trivialization by commodification... remembering Che Guevara has become a highly structured collective act of distinction" (431).

The artistic and political use of the image run counter to a branding effort by their very nature as non-commoditized and favorable stance toward appropriation for further artistic comment. Billboards, signs and all kinds of advertising had gradually disappeared from the Cuban public sphere under Castro's government from 1961 onwards. The focus in post-revolution Cuba shifted from celebrating the qualities of products and their consumption, to political state-run messaging explicitly designated as informative and educational. As part of 
the political signage, Che's image appears representing the Communist party, announcements regarding social works, and on the occasions of the anniversary of his death or other commemorative events. His face thus became a representation of the revolution accruing meanings on a specific register congruent with Guevara's own stance and prior governmental position. Additionally Cuban institutions (like the health system) with relations abroad used it to express messages of solidarity with what they perceived as similar revolutionary causes (Campos, personal communication). That is, an institutional use of the image for certain kinds of communication is politically but not commercially motivated. In Castro's Cuba, the image behaved in a metonymic, rather than metaphoric manner. Its relationship to the prototype was factually similar (icon) and contiguous (index), rather than imputed (symbol). ${ }^{11}$

Campos (personal communication) recalls that 1985 onward saw a resurgence of limited advertising activities in Cuba. In an effort to manage foreign firms and entities accustomed to publicity campaigns and advertising norms authorized to operate in Cuba, and Cuba established protective paternal policies to regulate the iconography of women and children, and policies prohibiting the use of national symbols, revolutionary martyrs and heroes. Campos provides this background to show that the Cuban government's use of the graphic image of Che was devoid of commercial interests. Political signage used by organizations are not sold, as Campos notes, but distributed through internal structures to fulfill social functions. However much one might push this as a branding effort, the image use in this case does not fulfill the requirements (personal communication).

According to Campos, after 1992, following the USSR's dissolution, which caused an economic crisis that annihilated $85 \%$ of Cuba's trade, the Cuban graphic industry was paralyzed due to lack of funds, and the sale of political posters to tourists and foreigners was initiated (personal communication). The sales included Korda's image of Guevara primarily as a cost recovery effort to keep people employed. Interestingly, that commercialization and sale was not extended to the Cuban public. In 1994, many people that thought the Cuban revolution had come to its end took advantage of the crisis, to publish and profit from reproductions of signs and posters with emblematic images of Che and of the revolution without crediting artists or the authorizing institutions. These historical events can be seen as forerunners to the copyright lawsuit that Korda eventually launched.

To make matters worse for the island, the US government saw the crisis as an opportunity to finish off the Cuban economy and bring down President Castro. On an initiative by Robert Torricelli, member of the US House of Representatives, The Torricelli Act was enacted in 1992. This act intensified the harshness of the economic blockade on Cuba by preventing food and medicine from being shipped to Cuba. ${ }^{12}$ An intense global solidarity movement from communities supporting Cuba emerged in response. As Cuba moved to establish ways to protect items it defined as crucial to Cuban national heritage, it installed copyright regulations for books and documents authorized to leave the country. Under these conditions, Guevara's widow Aleida Más created the Che Guevara Studies Centre, to house photos and documents salient to Guevara's historical legacy. For Campos, the Centre sees the prevention of the "improper use" or "for commercial ends" of the photos and posters as part of its task (personal communication). Since the Guerrillero Heroico is considered by Cubans to be part of their national heritage, they exercise some control over its use. The Guevara children are involved in the Centre and on occasion publicly criticize what they consider unscrupulous uses of the image of their father. As recently as 2008, The Guardian correspondent Rory Carroll wrote a piece called, "Guevara children denounce Che branding" (Saturday June 27) where Aleida Guevara "denounced the commercialization [sic] of her father's image ... 'Something that bothers me now is the appropriation of the figure of Che that has been used to make enemies from different classes. It's embarrassing." She added, "We don't want money, we demand respect." But Carroll is also compelled to comment on the image itself writing, "If you want to 
shift more products or give your corporate image a bit of edge, the Argentine revolutionary's face and name are there to be used, like commercial gold dust" and on Cuba, "Cuba's government has used the image to promote its revolution and to rake in tourist dollars through staterun stores which sell Che paraphernalia" (Guevara Children Denounce Che Branding online). The appeal of any image based on Korda's Guerrillero Heroico is indisputable; and so far, it seems inexhaustible. But Carroll's assumption regarding the state-run stores is inaccurate unless considered within the context of a specific reaction to a historical event. Additionally, the way copyrighting is mobilized and the way different actors are involved and influencing the image's use, are not a convincing indication that the Cuban state is moving toward a wholesale commercialization of the Guerrillero Heroico.

Campos describes Korda's daughter, Diana Díaz, the inheritor of her father Korda's work, as having the right to protect that photograph using copyright laws (personal communication). However, even her rights are within a specific framework. Cuban copyright policy holds that when an institution pays a salary for someone to occupy a post that permits their production of a work, he or she is recognized as the creator or author but the work is property of the institution. And when a work becomes iconic or emblematic, it grows to be part of the national heritage. Campos insists Che's image retains its original symbolism in Cuba, and does not function within the nation as a commercial logo on a souvenir (personal communication). Though Hernandez-Reguant's (2008) relegates the image of Che Guevara to an "object of state worship since his death in 1967" (254) for many on the island, the claim seems debatable.

\section{From Cuba with Love: Cubans "Exporting” Guevara's Image}

Cuban institutions use the Guerrillero Heroico in relations abroad to express messages of solidarity in that they are acting in the image of Che. For example doctors sent to aid Haitians after the 2010 earthquake wore Che Guevara T-shirts. This kind of official Cuban usage is exploited by Michael Casey to situate interest not along ideological grounds but "economic factors" (153). If we suppose someone just discovering that Cuba sends doctors and educators to developing nations might mistakenly call it a branding attempt, what kind of branding would they see it as? The presence of Cuban doctors in Bolivia in 2006 is described by Casey as a "re-brand[ing]" effort to portray Cuba "as a source of medicine and education services worldwide" (189). Yet the Cuban practice of sending doctors to hardship zones has been in place for decades (the first medical brigade of 58 doctors was sent to Algeria in 1963) and certainly does not receive sufficient press to warrant it a re-branding attempt. In fact, when Hurricane Katrina ripped through the southern United States in 2005, the Cuban government responded to the governor of Louisiana's call for aid offering

...within 48 hours 1,600 doctors, trained to deal with such catastrophes, would arrive with all the necessary equipment plus 36 tonnes of medical supplies. This offer, and another made directly to President George Bush, went unanswered. In the catastrophe at least 1,800 people, most of them poor, died for lack of aid and treatment. (Ospina)

In 2007, "Cuban doctors volunteering in Bolivia performed free cataract surgery for Mario Teran, the Bolivian army sergeant who killed the legendary guerrilla leader Ernesto "Che" Guevara in captivity" (AAP Brisbane Times). While Casey observed Cuban doctors wearing Che t-shirts in Bolivia, he failed to ask them why they did so. After all, Che Guevara was also a doctor. With all the focus on the image as commercial, it may benefit us to observe the anti-capitalist effect of Cuba's 25,000 volunteer doctors that by March 2006 were working in 68 nations. "This is more than even the World Health Organisation can deploy, while Médecins Sans Frontières sent only 2,040 doctors and nurses abroad in 2003, and 2,290 in 2004" (Ospina Le Monde). The message of free medical care is not lost on those who might otherwise not see a doctor in their entire lives. And visually, those people witness Cuban doctors acting in and through the image of Che (on their shirts), layering meanings onto it that are salient 
to their daily lives. It is for good reason that: "The medical associations are afraid that if the Cuban medics bring down prices or even offer some services free, medical treatment will cease to be a profitable, elitist service" (Ospina). If this is a branding effort, then it works to undermine capitalism itself, of which perhaps Guevara would approve. The practice has been sustained long term quietly saving many lives. ${ }^{13} \mathrm{I}$ have belaboured many details to show clearly how "branding" language fails to accurately depict the social and cultural impact of this image.

It is misleading to conflate Cuban use of the image in Bolivia with Bolivian appropriations but the way the discourse is mobilized is nevertheless useful to examine. For example, Bolivian salesmen like Fernando Porras use the Guevara image on all kinds of paraphernalia to target his market of 16-20 year olds (Casey 211). In Bolivia, President Evo Morales' government uses this Guevara image politically to link with notions of Cuban independence but also to remind its citizens of Guevara's death in Bolivia and the reasons behind it. For Casey, Porras' "shameless commercial exploitation" is tantamount to the Bolivian government's image use: "Porras might have been exploiting Che to sell rum and cola, but Morales and his supporters were using him to sell ideas" (213). He concludes, "what we find is the same symbol representing contradicting brands" (213). This statement no longer positions the image as a brand, reducing it instead to an ingredient, like the logo or symbol. But






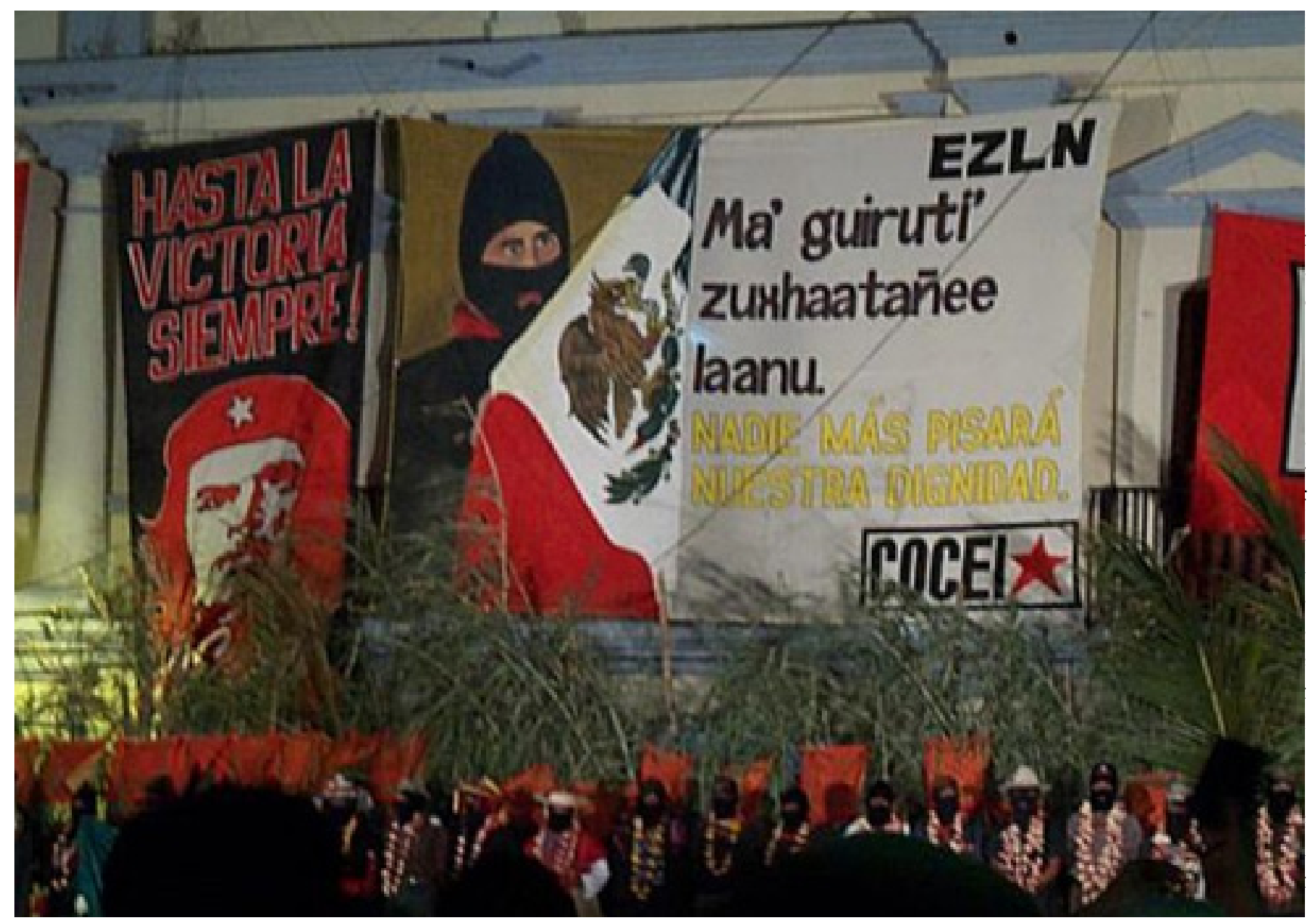

the same symbol cannot represent contradicting brands and still be viable. Therefore, Casey's readers are presented with a false analogy, that is, two cases pressed into service in a simplified and misleading parallel, yet not sufficiently parallel for readers to accept a claim of connection between them. The confusion that can result from such entwining and contradictory narratives might indicate that part of what is required in our image saturated societies is a more nuanced language to describe what is happening on the visual level, in other words we need more sophisticated visual semiotic literacies to decipher these discourses.

For understanding image use, Larson and Lizardo provide three frames. They state that the malleability of a memory (or an image) can be reduced in 3 ways (Olik and Robbins in L \& L) First actors using the memory of Che as instrumental symbol, second a canonical or institutional use of the image, and finally the routines marking consumer goods that keep the image visible on products such as T-shirts and posters (438). All three reductions have come into play for the Guerrillero Heroico's use inside and outside Cuba so far, but do not indicate a convincing shift in signifying practices of authorship because the photograph and its derivatives as 
of American-style consumer capitalism" (Larson \& Lizardo 426). If the image were to be considered a brand, it would be demonstrating instability, if not utter unreliability.

The professional literature on brand strategy examines different brand behaviours that might lead to some hypotheses regarding the behaviour and uses of this image. Moore examines three "insider phenomena of branding: genericide, ingredient branding, and socalled 'viral marketing'" (336) to probe the troubled relationship between a word (brand name) and an object (product). Viral marketing is less salient because it focuses on branding services and communications through email attachments where a sender inadvertently endorses the brand advertised in their messages. Genericide and ingredient branding however, may have some conceptual traction with the case of Guevara's image.

When a brand name becomes synonymous with a product regardless of who produces it, it becomes generic; so that the trademark is unable to carry the message producers want to communicate. Moore tells us, "Brand enters upon phenomenal reality as a mode of connection, of communication, between two parties" (335) when this fails it is called "genericide" because the loss of the identifying power of the name essentially kills the brand. Kleenex, for example, was once a brand, but since the word became so ubiquitous that it was used for any tissue, the trademark became insignificant.

Those clamouring for the Guerrillero Heroico to be considered a brand push for the image to be understood as the brand for intangible or virtual thing like the notion of rebellion. Leaving aside contradictions with the professional literature, let's think through the genericide scenario. The image has been used widely as some designer-cool type look and at the same time adapted to so many different kinds of anti-something struggles that Robert Massari "Italian publisher, wine merchant, and head of his country's Che Guevara Foundation" can say, "There are probably forty million in the world who have that image. And if you ask them what it means to them, they'd all have a different answer" (Casey 336). Not only would we have a genericide in the register of historical and political events with the delinking of the image from its context (and source meaning), and genericide commercially where it cannot bring to mind any one product, but we would also have genericide in terms of its inability to consistently link to one idea.

Erdem and Swait take up Kottler's definition of brand as a "name, term, sign, symbol or design, or a combination of them which is intended to identify the goods and services of one seller or a group of sellers and to differentiate them from those of competitors" (Erdem and Swait 191). More importantly, they emphasize the crucial roles played by brands as a factor in consumer choice (191). No Guerrillero Heroico brand of any particular product for a consumer to even be able to consider, or choose between, exists. Since the product is virtually irrelevant, can we consider this a classic case of genericide in the way branding strategists would classify it? Not really. It is on another register and does not make one product generic. If we consider that people do not buy products, but brands, anything with Che's face on it will sell regardless of its inability to communicate the goals of a seller, so it sells but not as a brand.

In ingredient branding, the product rather than the name is vulnerable, "one branded product is absorbed or incorporated into another (think NutraSweet, as a branded ingredient of Diet Pepsi, or 'Intel Inside')" (Moore 337). Because consumers can tune in to the ingredient and consume the "host product" almost as an effect rather than a cause of their choice, the branded ingredient can lift off and adhere to other hosts thereby making the product vulnerable. Within the ingredient branding phenomenon, there is a possibility of "image transfer" (Moore 349). In other words, when paired with a leading manufacturer, "the ingredient brand takes advantage of their premium image.... [and] signals that the ingredient is of a high quality" (Moore 349). Additionally, the branded ingredient can absorb the status of the host brand by association, and can subsequently pass it on to other possible host brands. Ingredient branding makes a product vulnerable 
because the ingredient can just as easily attach to a competing product thus making the host product marginal and weakening its inherent perceived value in the marketplace. If the branded ingredient is transferred elsewhere, the original product could easily disappear.

Uniquely in the case of the Guerrillero Heroico, the ingredient is a virtual and fluid one in that it is whatever the image may represent to a given individual. The commercial rhetorical gesture of putting Che Guevara's face on a pot of lip-gloss thus shares meaning with (and gains cultural capital and power from) a broad social movement, however illegitimately. The product is more or less irrelevant, in the way we have seen for objects attached to branded ingredients and is clearly a case of unsuccessful branding. Furthermore, in this case the ingredient can behave in unpredictable ways. Kopytoff reminds us that commoditization is "best looked at as a process of becoming rather than an all-or-none state of being" (73). He adds, "extensive commoditization is not a feature of commoditization per se, but of the exchange technology... associated with it..."(73), so that the way this image of Che is mobilized has a great deal to do with its immediate context.

Durkheim held that societies needed to set aside a certain portion of their environment marking it as "sacred." Things marked by societies as sacred, such as monuments, often become so through a process of singularization where they are situated as outside the commodity sphere. A diamond, for example, becomes a crown jewel when it takes part in a regent's regalia. They can also be singularized through restriction of numbers. It is important to recall that the state of being a non-commodity, however, is not equal to being sacred. Kopytoff explains how something can be priceless by being above level or below (e.g. Manioc is not tradable). Commodities can be de-activated by becoming personalized, or terminal in that they expire and cannot continue to be exchanged, as in the case of food or services. Additionally, public opinion is against commoditizing what has publicly been marked as singular and thus sacred. African art, for example becomes "collectible" to mask the feeling from before where it was immoral to sell it for money (Kopytoff 7079). People also yearn for singularization as evidenced by cultures of collecting. The paradox is: "as one makes things more singular and worthy of being collected, thus more valuable and if valuable they acquire a price and become a commodity and their singularity is to that extent undermined" (Kopytoff 81).

The singularity of something is confirmed by its periodic appearance in commodity sphere: a painting by Picasso for instance "shows its 'priceless-ness' by the feeling it's worth more than the money...people feel need to 'defend' themselves against 'charge' of 'merchandising art'" (Kopytoff 83). The status of a thing is ambiguous except at actual point of sale. Through a Marxist lens, one would understand the commodity value as determined by social relations, and socially endowed with a fetishlike power unrelated to its practical worth.

If Moore is correct in saying, "Successful branding, then, is successful communication, successful in the sense that it 'secures uptake' from its interlocutors in the market" (335), then the Guerrillero Heroico cannot be considered successful as a brand. Some individuals may have just as many reasons not to buy a product with this image on it as others do who do buy the product; culture, class and ethnic identity of course come into play. Perhaps the contested terrain of this image and its progeny can be illuminated by tracing its activities as art and by looking at how artists appropriate and manipulate the image?

\section{Art of Appropriation-Appropriation of Art}

Copyright laws are part and parcel of institutional use of the Guerrillero Heroico by states and organizations for ideological purposes, and commercial use by corporations as radical chic bereft of historical memory. In a different way, these laws also bear on uses by groups like self-identified left-wing soccer supporters (such as the South Winners of Olympique de Marseille and their passionate north-south rivalry with Paris), "landless workers in Brazil (1997), striking university students in Mexico City (1999), peace activists in Italy (2002)" (Larson \& Lizardo 429). Often such groups take the image as a marker of group solidarity and are usually 
seen using a mass produced version of the Guerrillero Heroico.

The befuddled claims that this image owes its fame, wide reproduction, and distribution to its not being copyrighted are due partly to their overlooking its status as fodder for artists. These kinds of claims also ignore the historical fact that before 1976 in the United States, the term of copyright was only twenty-eight years after which the license would have to be renewed otherwise the work would become part of the public domain. Had the US Congress not changed copyright law, Guerrillero Heroico, along with a multitude of other works, would likely still belong in the public domain today. ${ }^{16}$

The unique situation of this photograph as the most reproduced image in the history of photography, and its copious derivatives, reveals how the creation of value in Western society is inextricable from the cultural context of a particular object. Additionally, collective memory research indicates "that the culture industry that sells his image and the antisystemic movements that revere him are emblematic of a contest over his memory" (Larson \& Lizardo 447). It is important to recall that even Time magazine recognizes Ernesto Guevara as one of the top 100 most influential people of the $20^{\text {th }}$ century; this is not a photograph of just anyone. Tension exists in every economy between forces driving toward commoditization, countered by those of cultures and individuals who discriminate, classify, compare and sacralise: they are intertwined in multiple and subtle ways, and are constantly in flux. Che Guevara's image has not been domesticated by capitalism or the tension around it would not exist. Can we learn from what happens with the Guerrillero Heroico in the hands of artists and individual hand-made vernacular appropriations and figurations, borrowings or extractions, and inspirations bestowed by this image?

Artists have always appropriated or quoted ideas, techniques, approaches, colours, shapes, or a combination of these. Whether borrowing from a master to whom they were apprenticed or from a combination of inspiring images or even from a natural, environmental, or object surrounding, the appropriation of material for artistic purposes has been widely acknowledged as standard practice. However, with the blurring of the boundaries between material and virtual objects, and shifting notions of ownership, more and more artists are being accused of stealing images and ideas. Correspondingly, the practice of policing the image-scape is also growing. Nevertheless, thanks in part to digital media, proliferation of derivative arts continues unabated. Part of this spread could be due to the unprecedented growth of "postproduction $\operatorname{art}^{17}$ " in French art historian Nicolas Bourriaud's (2005) terminology. In Romana Cohen's interview with for PLAZM magazine, Cushing states, "creative appropriation is the lingua franca of activists, and there is no shame in artful reinterpretation of powerful imagery" (Cohen).

In a fascinating interview with legendary French filmmaker Jean-Luc Godard, Lañamme and Kaganski ask him whether he claims rights to his movie images. Godard responds in the negative and asserts that although many artists appropriate his images online, he does not feel robbed. He explains his position through a series of comparisons: “... Norman Mailer's book on Henry Miller, is $80 \%$ Miller and 20\% Mailer. In the sciences, no scientist pays copyright fees to use the formula developed by a colleague...in my film there is another kind of borrowing not citations simply extractions. Like an injection that takes a blood sample for analysis" (Lañamme and Kaganski).

Godard explains his appropriation of a scene from Agnès Varda's Les Plages d'Agnès as artistic commentary rather than a violation of any kind. Reasoning that the metaphor in Varda's film was ideal for his purposes, he re-contextualized those images: "Those images seemed perfect for what I wanted to do...It was exactly what I wanted to express. So I grabbed the images because they already existed" (Lañamme and Kaganski).

For Godard then, as is the case for many artists, the Varda scene was simply viewed as pre-existing material that he was free to use artistically. His philosophy is revealing: "I do not believe in the concept of work. There 
are works, there are some new, but the work as a whole, the great work, is something that does not interest me. I prefer to talk of a road" (Lañamme and Kaganski). The processual, unfinished nature of Godard's view of his art leads him to view his experiences of the works of others as part of a living mental, spiritual or emotional nourishment through his incorporating, consuming, digesting and changing others' creations in order to come up with a layered, nuanced and allusive piece that participates in additional conversations, a polyphonic approach. Perhaps this kind of "stealing" is behind Pablo Picasso's long misunderstood platitude, "Good artists copy, great artists steal." In other words, it is not simply about adopting ideas from others, or even of appropriating aesthetic flourishes and stylings practiced by master artists. Rather, the zone of activity is one where the Guerrillero Heroico in this case, inhabits different renderings and works as part of the artists' visual vocabulary and commentary through creative artifice on a political or social idea. The "stealing" of this image, allows it to both participate in salient conversations, and add its own intonation.

However, there is a code of behavior amongst artists, particularly those working in political ways. Part of the

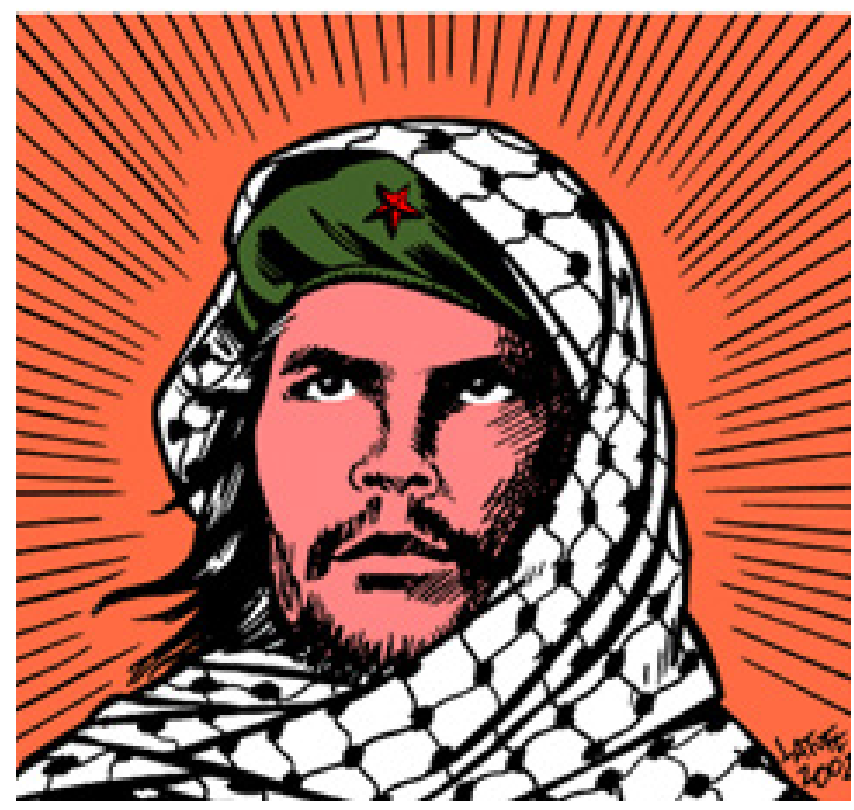

concern artists such as Mark Vallen voice, is that with the soaring use, reuse and expropriation of images, the "relentless mining and distortion of history will turn out to be detrimental for art, leaving it hollowed-out and meaningless in the process" (Cohen). As we have noted, this is similar to debates around the Guerrillero Heroico. Vallen and other artist/activists such as Lincoln Cushing, Josh MacPhee, and Favianna Rodriguez have publicly discussed the nature of plagiarism vis-à-vis subvertisement and parody. Cushing expresses the complex unwritten understanding between artists as being highly conditioned: “...IF it's noncommercial, and IF one isn't claiming personal credit, and IF it's helping a progressive cause, it's pretty much OK to grab other art

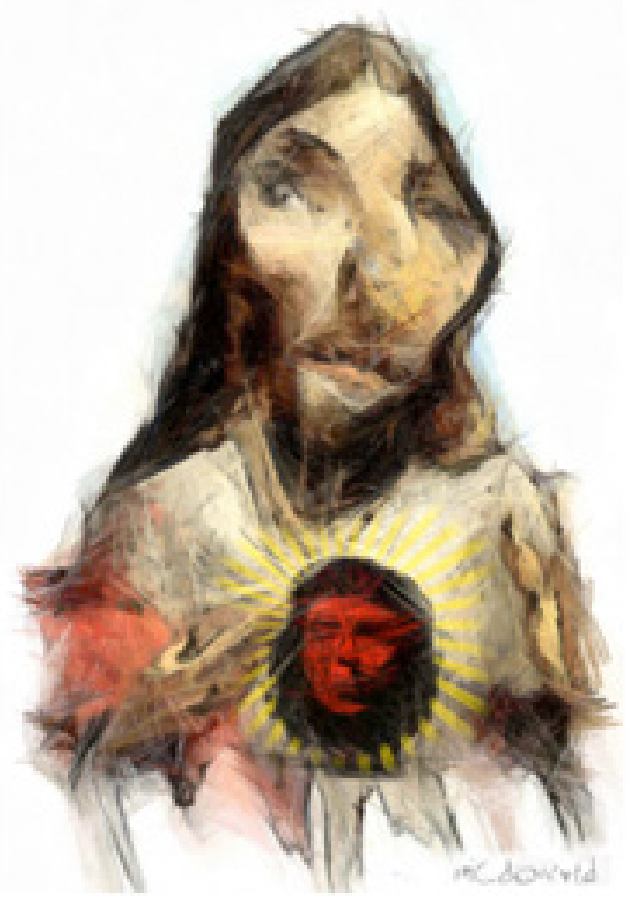

and use it" (online). The model is less dominant than it was during the 1960s but has found new formulations in agreements such as those configured through CopyLeft and Creative Commons. Cushing sees the guidelines as a beginning, but feels they need to go farther to protect the history or enable the tracing of the trajectory of an artwork (Cohen). 
The issue for Cushing and others is in terms of a moral economy where an artist who intentionally copies artworks must not pretend to have been their originator, or attempt to deceive viewers. Not only do Cushing and Vallen advocate for a transparent process, but they also support the appropriation of existing art to maintain the spirit in which it was created. For example, if an image was created for political and nonprofit purposes, then its derivatives must remain free of copyright restrictions. Artists who would profit from an exploitation of images such as the Guerrillero Heroico are seen as sellouts that ally with those very forces that the image was seen to protest against. MacPhee notes: “... Posters and graphics made in the heat of political struggles are often made by anonymous individuals or groups that want to keep the images in the public domain for use in further struggle" and decries those who would "personally capitalize on the generosity of others and privatize and enclose the visual commons" (Vallen ). In the debate on attribution and recognition, this kind of "stealing" is seen as a copywrong, to adopt Siva Vaidhyanathan's neologism, contributing to historical amnesia and cultural imperialism. The metamorphosis of corporatizing a work shifts it from being considered art to the realm of brands. The difference does not merely reside in the articulation but in the nexus of social and cultural circumstances. Acknowledging that the language of branding "is a product of modern U.S. capitalism" Casey claims, "it is really just a commercially practical way to describe how symbols and images are used in many forms of communication" (340). And yet, as many of the examples I have cited show, not all communication is commercial, neither is all adoption or use of symbolic representation.

Among the many artists inspired by the image of Che Guevara based on the Guerrillero Heroico are the political cartoonists Carlos Latuff and Allan McDonald. They can be characterized as "semionauts" (Bourriaud 18 ) in that they invent paths through visual culture by using pre-existing forms and imagining links and relations between a network of signs. Skillfully and eloquently they navigate a vast sea of images cartographically following ephemeral and temporary lines in order to reveal alternative meanings, while at the same time fusing moments of production and consumption. Thus, "the culture of use implies a profound transformation of the status of the work of art: going beyond its traditional role as a receptacle of the artist's vision, it now functions as an active agent, a musical score, an unfolding scenario, a framework that possesses autonomy and materiality to varying degrees" (Bourriaud 20).

Latuff is particularly known for his provocative and controversial work on the Palestinian-Israeli challenging mainstream versions of the conflict. The kaffiyeh, an Arab-Palestinian scarf and Che are brought together as two global symbols of resistance against oppression and coloniality, bringing into alliance the struggles in Latin America with those in the Middle East. This particular image was also reincarnated as a t-shirt and worn in protest marches in England and elsewhere.

Latuff comments, "my intention is to associate a universal, established and popular icon of resistance with the Palestinian struggle for independence. Using well-known symbols and giving them a new dimension and meaning is part of my job as a political cartoonist and image-maker" (personal communication). Likewise, McDonald, who has dedicated a great deal of his life to anticapitalist struggle and social and political criticism, find inspiration in the image. In his articulation, the Korda image becomes the "sacred" heart of Jesus, and explicitly allies their spirits but places Che as the inspiration, or source at the centre of Christ in an odd thought-provoking alliance.

Isee these images as being beyond the art of appropriation, inhabiting instead "...a culture of the use of forms, a culture of constant activity of signs based on a collective ideal of sharing" (Bourriaud 17). For artists involved in programming forms rather than producing them, Che's face has become a tool to manipulate and interrogate in order to produce different results. Interestingly this image manifesting from the original photograph is also acting in its own right by acting upon the artist affectively being "independently capable of stirring the forces of human imagination and of tapping into 
deep-seated longings for a better world" (Casey 342). The continuing motivation of these and other artists to use this image, confirms its persistent resonance in the visual public sphere; it continues to speak, and both artists and their audiences are listening.

\section{Conclusion}

Hernandez-Reguant's finish where he states, "However, at the end of the affair, it was still unclear whether the now copyrighted Che - and his legacy to Cuban late socialism - had really beaten the forces of capitalism or rather surreptitiously joined them" (256) is really just the beginning. True, many would like to dismiss this image as having been incorporated into the market logic of the culture industry, and consequently losing its power as a political symbol. Most would agree that the Guerrillero Heroico lives a "...strange and by now unstoppable afterlife since his murder in Bolivia in 1967, at the age of 39" (Poyner 34). Despite having strong characteristics of a material commodity in its ability to be a repository for added value, it also resists the force of iconographic commercialization and continues to be a viable political banner. In part, this may be because of its material iterations. "Webb Keane (2003) ...observes that part of the power of material objects in society consists of their openness to 'external' events and their resulting potential for mediating the introduction of 'contingency' into even the most hegemonic of social orders” (Moore 334).

The exceptional case of Che Guevara, embodies the contest visibly being waged between the culture industry and anti-systemic movements that some scholars contend "is shaped and manipulated by elites in order to establish dominant, hegemonic meanings and interpretations of the past, while others argue that groups can reconstruct and recover memories in order to imbue them with new counterhegemonic interpretations (Bromberg and Fine 2002; Fine qtd in Larson \& Lizardo 427). Either way, the presumption that Guevara's image is little more than a fashionable accessory sapped of all political meaning, or that processes of commoditization have undermined its power to signify and activate political or ideological action is countered by Larson and Lizardo's (2007) conclusion that "it is by no means clear that Che Guevara has been de-politicized in the face of unbridled commercialism...” (429).

The reality is far more complex: artists have shown through their adoption and appropriation of this image that commodifying forces and processes of radicalization can coexist: "In fact, the collective consumption of material culture objects might be associated with a renewed radicalization of political struggles and a strengthening of collective identities and ideological commitments" (Larson \& Lizardo 449). As a result of their extensive work Larson and Lizardo advise us to consider that the material consumption of Che Guevara's image can actually coexist with commitments to political resistance despite the ominous intonations of mass media scholars, "commoditization does not result in the irrevocable termination of the power of political images and symbols" (450).

Branding attempts to insert stories between ourselves and objects in a way that foster desire of the object in order to participate in a specific story. In this way, branding is geared to interrupt our own processes of singularization (Kopytoff), so that a more homogenous story can become a source of profit. These shallow "brand sagas" (Twitchell 489) are discussed in Brand Nation through a review of commercial strategies adopted by museums, universities, and other institutions as if to prove everything is a brand.

Twitchell (2004) notes, "Transient materialism. Secular epiphany. Yes, brand owners talk about the soul of their brands, brand aura, and of their brands as icons, to be sure. By this they mean that their brands have a symbolic, almost a religious significance, which goes way beyond their worth as products" (488-489). These discourses of "brand soul" and "brand icon" (488) and the "process of spiritualizing commercial brands" (488) are supported by Douglas Atkin, in The Culting of Brands as a way for brand owners to copy churches and cults in turning their brands into some kind of source of community (Casey 306) in order to promote goodwill and broaden the meaning of branding to make it all- 
encompassing of any symbolic representation under which people can group together. To some extent this strategy succeeds. "How else to explain something so irrational as Evian water, a Dior purse, or a Martha Stewart rolling pin?" (Twitchell 488). Nevertheless, this tactic does not succeed in all cases, particularly in such politically charged and contested cases such as that of the Guerrillero Heroico.

While the "intrinsic logic of brand protection" follows the notion that the brand's intangibility makes "brand owners worry about the fragility of their vital piece of property," since its value can vanish overnight if it acquires a bad reputation. Casey believes the Korda estate lawyers are doing something similar since they are demarcating acceptable and non-acceptable usage of the image (335). In spite of this, it is just as likely that the usage of the Guerrillero Heroico as governed by the Cuban Government, Guevara's family, and Korda's daughter Diana Díaz represents an awareness of and compatibility with the meaning of Guevara's own death and life. By the same token, John Berger found emotional correspondence between Guevara and his death as a result of his attempt to change the world because "anything less would have meant that he found the 'intolerable' tolerable" (Berger 207). For John Berger (1975), Guevara "represented a decision, a conclusion" (207).

In a letter to his parents when he left Cuba, Guevara wrote: "Now a will-power that I have polished with an artist's attention will support my feeble legs and tiredout lungs. I will make it.” [Guevara 113, (translation by Berger)] (208). Certain of his own death in the fight against imperialism, Guevara called for those who would embrace the same ideals to welcome death as long as "our battle-cry, may have reached some receptive ear and another hand may be extended to wield our weapons..." (1a "Vietnam Must Not Stand Alone" New Left Review, no. 43 [London, 1967)] (Berger 204). Responding to his call, millions interpellated by the Guerrillero Heroico around the World take up the image as a way of noting the intolerable state of the world, the need to change it, and the commitment (to varying degrees) to participate in that change. To those who re-render this image on the streets, (in the vernacular handmade sense such as that of a graffiti artist on the street in Guatemala), attempts to brand products with this image of Che fail absolutely and its copyrighting is irrelevant. Thus, the image continues to function as a virtual prosthetic of the man himself, and of his ideas. Both continue to be politically charged and salient.

\section{Notes}

1. Translated from the Spanish interview as, "copyright really has no reason to exist. I don't have rights. On the contrary, I have obligations."

2. The most notable variation being Irish artist Jim Fitzpatrick's 1967 stylized poster featuring a two-tone face in black and white on a bright red background. Fitzpatrick distributed his poster widely in Europe. In 2008, he signed over the copyright of his image to the William Soler Pediatric Cardiology Hospital in Cuba.

3. Street graffiti of Che Guevara wearing a Che t-shirt in Bergen, Norway from Wikipedia (public domain) available at http://en.wikipedia.org/wiki/Che_Guevara in_popular_culture. Unless otherwise noted, all photographs are my own.

4. Simultaneously in October 1968, Antonio Pérez "ÑIKO" designed a poster for the Comisión de Orientación Revolucionaria (COR), it was not printed in that historical juncture where the testimonial photograph was preferred as the way to reveal the energetic and vigorous image of Che. In 1968, the design was reformulated and the offset printed poster had a communicative effect and symbolic meaning that later became representative of Cuban graphic art (Campos, personal communication). Ese cartel se diseñó en octubre de 1967, cuando ya se confirmó su muerte y no se imprimió y el que se reprodujo fue el del texto de "Che la juventud entonara tu canto con gritos de guerra y de victoria" que lo editó el Comité Nacional de la Unión de la Jóvenes Comunistas (UJC), que poseía una foto , a medio cuerpo, con su boina y el uniforme 
verde oliva también de Korda y que la había tomado en un acto por el quinto aniversario de la Revolución. Ese cartel de la UJC amaneció colocado en todas las calles y avenidas.

5. Full original text of Castro's speech in Spanish available here: file:///Users/Carolina/Desktop/Cartel\%20Cubano/ Discurso\%20del\%20Comandante\%20Fidel\%20 Castro\%20Ruz\%20el\%2018\%20de\%20octubre\%20 de\%201967\%20-\%20Wikisource.htm

6. Campos' work centres on the Cuban political poster and poster art on which he has published extensively. $\mathrm{He}$ is also a member of the Cuban Association of the United Nations and the Cuban Historians Association among others.

7. Article $6 \mathrm{~b}$ of the Berne Convention for the Protection of Literary and Artistic works states: "(1) Independently of the author's economic rights, and even after the transfer of the said rights, the author shall have the right to claim authorship of the work and to object to any distortion, mutilation or other modification of, or other derogatory action in relation to, the said work, which would be prejudicial to his honor or reputation" (1971, online).

8. One question to be raised here is whether it is even appropriate to attempt the branding of political art. Unlike most corporate brands, the photograph was intended for a different public and purpose (historical documentation). So is the debate about the branding of Che's image itself not problematic? In a sense, a commercial practice is being applied to a cultural artefact that has nothing to do with the province of commerce. The debate over intention verses reception is ongoing.

9. "Accenture Plc and AT\&T dropped him as their pitch man after he became engulfed in allegations of multiple extramarital affairs following a minor car accident outside his Florida home on Nov. 27"

10. Inexplicably, Miami is included in the book's section on Latin America, "Part II: Mimicking a Martyr: San
Ernesto of Latin America" (table of contents). By having it placed last, after Argentina, Bolivia and Venezuela it serves the rhetorical purpose of undermining the prior chapters with its more disparaging tone and praise of ex-CIA assassins.

11. Following CS Peirce's three principal semiotic classifications for signs; icon, index, and symbol.

12. The Torricelli act designed to paralyze the Cuban economy and cause the fall of the president forbids American companies, and subsidiaries abroad, from engaging in any trade with Cuba. Foreign ships using American ports were forbidden from Cuban ports for a period of 180 days and foreign ships returning from Cuba were also detained. Cuban families living in the U. S. were barred from sending any cash remittances to Cuba. Torricelli corruption - http://www.pbs.org/newshour/ bb/congress/july-dec02/bkgdtorricelli_09-30.htmlhttp:// www.nytimes.com/2007/08/24/nyregion/24torricelli. html?_r=1

13. In 2005 alone, the barefoot doctors program helped the most poverty-stricken of six Latin American countries and 20 in Africa. The staff delivered more than half a million babies, carried out 1,657,867 operations and gave almost 9 million vaccinations. In Haiti, Cuba has been providing 2,500 doctors and as much medicine as its economy permits since 1998 .

14. Journalist Teresa Bo (2010) writes, "Colombia is still at war. You find trenches in every corner, tanks, Blackhawk helicopters and lots of soldiers. Fighting takes place here almost every day ... But we managed to find the left-wing FARC rebels, who are still fighting the Colombian government. ... They said that a fight with the military was coming.... Commander Duber: "Our main enemy is president Uribe and the armed forces. ... There are elections in Colombia. People can vote for whom they want. But we will continue fighting. The ideology of the FARC is to win or die, that's what Che Guevara said," Duber told us. In Cauca the fighting is still ongoing. Duber adds: "Presidente Uribe offers money [and] cars to those guerrillas who turn themselves 
in. Those who sell themselves are not guerrillas. They should give that money to those who are still starving in this country. We don't need it."

Photo credit: "Guerrillero colombiano de las FARC, montañas del Caquetá, Colombia" (2001) by Venezuelan photographer Pedro Ruíz -- http://www.zonezero.com/ kordasche/ruiz/ruiz.html.

15. Indymedia photograph under copyleft license.

16. In 1976, Congress decided that the term of copyright protection should be life of the author plus 50 years. See also illegal-art, an organization devoted to collecting artworks that challenge current conventions of intellectual property law, or that have been involved in litigation for infringing on someone's copyright. Launched by the magazine Stay Free! ... a publication that critically analyses mass culture commercialization, .... Their work proves that in the remix and "copy \& paste" age, the right to criticism, parody and freedom of speech is easily repressed through the demands of culture mega-corporations using the current restrictive regime to their advantage.

17. Postproduction art is art that uses other readymades following the notion originated by surrealist artist Marcel Duchamp, and builds a piece on or with those already circulating. A handy example would be the DJ music scene where music is "sampled" or quoted in innovative ways. People recognize the citation and understand how the DJ is playing with it; they are part of the story.

\section{Works Cited}

Australian Associated Press (AAP). Brisbane Times, 30 Sept. 2007. Web. 24 Apr. 2010. <http://news. brisbanetimes.com.au/world/cuban-doctors-help-cheguevaras-killer-20070930-11s1.html>.

Berger, John. "Che Guevara: The Moral Factor." The Urban Review 83 (1975): 202-08. Print.

Bermúdez, Jorge R. Antología Visual Ernesto Che
Guevara En La Plástica Y La Gráfica Cubanas. La Habana: Letras Cubanas, 2006. Print.

Berne Convention for the Protection of Literary and Artistic works. Article 6bis. 1971. Web. 15 July 2011. <http://zvon.org/law/r/bern.html\#Keywords author>

Bo, Teresa. "The FARC Side of the Story." Weblog post. Al Jazeera English. 20 June 2010. Web. 20 June 2010. $<$ http://blogs.aljazeera.net/americas/2010/06/20/farcside-story-0?sms_ss=email>.

Bourriaud, Nicolas. Postproduction: Culture as Screenplay: How Art Reprograms the World. Trans. Herman, J. New York: Lukas \& Sternberg, 2005. Print.

Bragg, Billy. "Waiting for the great leap forwards" Between the Wars EP 1985. LP.

Carroll, Rory. "Guevara Children Denounce Che Branding." The Guardian: International Section. 7 June 2008. Web. 12 Oct. 2010.

Carvajal, D. "From Rebel to Pop Icon.” New York Times 30 Apr. 1997: C11. Print.

Campos, Reinaldo Morales. Personal communications. December 2, 2010 to February 17, 2011.

Casey, Michael. Che's Afterlife: The Legacy of an Image. New York: Vintage Books, 2009. Print.

"Castro Rules Out Elections in Cuba." New York Times 2 May 1961: A1. Print.

Cohen, R. "Lincoln Cushing: On the Past, Present \& Future of the Political Poster." PLAZM magazine. Eds. Raymond, Jon and Tiffany Lee Brown. Portland, Oregon: Joshua Berger, 2007. Vol. 2010. Print.

Davis, Lloyd. Guise and Disguise: Rhetoric and Characterization in the English Renaissance. Toronto: University of Toronto, 1993. Print.

Elliot, Stuart. "Is the Tiger Woods Brand Beyond Repair?" New York Times. 19 Feb. 2010. Web. 5 Mar. 2010. 
<http://mediadecoder.blogs.nytimes.com/2010/02/19/isthe-tiger-woods-brand-beyond-repair/>.

Erdem, Tulin, and Joffre Swait. "Brand Credibility, Brand Consideration, and Choice." Journal of Consumer Research 31 (2004): 191-98. Print.

Hernandez-Reguant, Ariana. "Copyrighting Che: Art and Authorship under Cuban Late Socialism." The Anthropology of Globalization: A Reader. Eds. Inda, Jonathan Xavier and Renato Rosaldo. Malden and Oxford: Blackwell Publishing, 2008. 254-76. Print.

Isserman, Maurice. "Afterimages." The Nation 10 June 2009. Web. 17 July 2010. <http://www.thenation.com/ $\mathrm{doc} / 20090629 /$ isserman $>$.

"Korda Photograph." UNC School of Information and Library Science. Web. 14 Jan. 2009. <http://www.ils. unc.edu/ michm/Che/korda.html>.

Kopytoff, Igor. "The Cultural Biography of Things: Commoditization as Process." The Social Life of Things Commodities in Cultural Perspective. Ed. Arjun Appadurai. Cambridge: Cambridge UP, 1986. 64-91. Print.

Lañamme, J.M, and S. Kaganski. "Entrevista Con El Director De Cine Jean-Luc Godard.” El Cultural [Spain] 3 Dec. 2010, Online Ed., Cine sec. Web. 6 Dec. 2010 $<$ http://vozentrerriana.blogspot.com/2010/12/jean-lucgodard.html>.

Larson, Jeff A, and Omar Lizardo. "Generations, Identities, and the Collective Memory of Che Guevara." Sociological Forum 224 (2007): 425-51. Print.

Moore, Robert E. "From Genericide to Viral Marketing: On 'Brand'." Language \& Communication 23 (2003): 331-57. Print.

Ospina, Hernando Calvo. "Cuba Exports Health.” Le Monde Diplomatique. 11 Aug. 2006, English ed. Print. Paz, José Aurelio. «Alberto Korda.» Avizora. 2001. Web.
23 Nov. 2009. <http://www.avizora.com/publicaciones/ reportajes_y_entrevistas/textos/alberto_korda_0095. htm>.

Poyner, Rick. «Join the Revolution...Or Buy the T-Shirt.» $V$ \& A Magazine Summer 2006: 34-41. Print.

Rosenberg, Tina. "The World Resurrects Che; But the Latin Left Prefers Helmut Kohl.” New York Times. 20 July 1997: E14. Print.

Silver, David. "Would Che Have Turned Capitalist? Never!"." New York Times 23 July 1997, Letters to the Editor sec.: A20. Print.

Sridhar, V. "Seeing with the Heart." In Frontline, (19:25, December 7, 2002) http://www.hinduonnet.com/fline/ fl1925/stories/20021220000306600.htm (accessed July 20, 2004).

Storey, John. Cultural Theory and Popular Culture: An Introduction. London: Prentice Hall, 2001. Print.

Twitchell, James B. "Reflections and Reviews: An English Teacher Looks at Branding." Journal of Consumer Research 312 (2004): 484-89. Print.

Vallen, Mark. "Obey Plagiarist Shepard Fairey." HeyOKmagazine. Vol. 2010.

Print.

Wittgenstein, Ludwig. Philosophical Investigations;. Oxford: Blackwell, 1968.Print.

"Woods Still Top Athlete Name Brand." Online posting. ESPN.com News Services. 5 Feb. 2010. Web. 6 Oct. 2010. <http://sports.espn.go.com/golf/news/ story? $\mathrm{id}=4887062>$. 


\section{Bio}

Dr. Carolina Cambre received her doctorate from the Policy Studies in the Education department at the University of Alberta. Her dissertation research was titled The Politics of the Face: Manifestations of Che Guevara's Image and its Renderings, Progeny, and Agency. Currently she is teaching courses in Mass Media and Advertising for the University of Western Ontario's Sociology department. Virtually, she can be found here: http://ualberta.academia.edu/mariacarolinacambre/ About

Bio

Dr. Carolina Cambre est titulaire d'un doctorat en éducation, avec spécialisation en politiques de l'enseignement de l'Université d'Alberta, avec une thèse intitulee "The Politics of the Face: Manifestations of Che Guevara's Image and its Renderings, Progeny, and Agency ». Actuellement, elle enseigne des cours de médias et de publicité au département de sociologie de l'Université de Western Ontario. On peut la trouver en ligne à cette adresse : http://ualberta.academia.edu/ mariacarolinacambre/About 